\title{
The thematic content analysis of the scales used in citizenship education
}

\author{
Melehat Gezer (iD) 1 ,
}

${ }^{1}$ Dicle University, Faculty of Education, Department of Social Studies Teaching, Diyarbakır, Turkiye

\author{
ARTICLE HISTORY \\ Received: Feb. 22, 2021 \\ Revised: Jan. 17, 2022 \\ Accepted: Feb. 02, 2022 \\ Keywords: \\ Citizenship, \\ Citizenship education, \\ Scale development, \\ Scale adaptation, \\ Thematic content analysis.
}

\begin{abstract}
This study aimed to scrutinize the scales used in citizenship education in Turkey through thematic content analysis. In the study, all of the scales developed/adapted within the scope of citizenship education without a year limitation were reviewed and 56 scales found in these studies were evaluated. The document analysis was used as the method of data collection. It was determined that the scales examined in the study were mostly published within the scope of doctoral dissertations and articles. Most of the scales were developed/adapted in 2016, a great majority of which were developed by researchers themselves whereas a small number of which were adapted from other cultures into Turkish. The most frequently used key words in the studies where the scales were available were "citizenship", "social studies" and "citizenship education". The sample mostly used in the scales were composed of university students and the most frequently used sample size included 201-300 participants. It was concluded that the relevant scales considered multi-factor structures in relation to citizenship. In addition, a number of deficiencies were found in analysing the psychometric properties and recommendations were made accordingly.
\end{abstract}

\section{INTRODUCTION}

Citizenship, which originated from the word citizen in antique Greek city states, today represents individuals' membership/loyalty to the state or political community they belong to. In addition to having a number of rights as a result of such adherence, citizens also take on certain duties and responsibilities. Citizenship as a concept which has political, legal and social bases and a dynamic phenomenon has changed throughout history. This concept has broadened more throughout history on the axis of social and economic changes and has taken on new dimensions. The concept has gone beyond expressing loyalty to a state or a community and acquired transnational properties especially along with globalisation and with the advance of technology. The reasons for the transformation in the conception of citizenship include several factors such as global environmental problems (the unproportioned use of nuclear energy-based products, global warming, climate change, environmental pollution, extinction of species of animals, etc.), the need for digital literacy (problems related to confidentiality and protection of personal information, cyber-attacks, cyber loafing, cyber bullying, etc.) and the protection of minority rights (not paying attention to the law of immigration and refuge, not giving the right of self-management, refusing cultural diversity, increase in racist movements, etc.). The abovementioned problems concern not only a community but also the whole universe and pose a

\footnotetext{
"CONTACT: Melehat Gezer $\square$ melehatgezer@gmail.com Dicle University, Faculty of Education, Department of Educational Sciences, Social Studies Teaching, Diyarbakır, Turkiye
} 
threat to all humanity. It is a reality that those problems cannot be eliminated with traditional mentality of citizenship (Özel, 2007) because it is no longer considered adequate to be aware of responsibilities for one's country and to perform the duties. Citizens who have responsibilities for the whole world, who choose to play a part in solving the problems, and who take action accordingly are needed today (Şahin, et al., 2016). This situation has necessitated the changes in the types of citizens that many countries wish to raise or have (Eurydice, 2017; Gezer, 2020).

Strengthening citizenship competencies through education has recently become an important theme in politics, the public, and the scientific world (Eurydice 2012, 2017). Basically, it is aimed, with citizenship education, to ensure the active participation of individuals in political and social life as free individuals, to raise awareness of individuals about the protection and support of the democratic system with common democratic values (Loobuyck, 2021), and to prepare individuals for citizenship with the awareness of their citizenship duties and responsibilities (Kerr, 1999). However, there is no common view on the content of citizenship education. Therefore, the citizenship education includes diverse content and objectives. Some countries may place more emphasis on ensuring that students have the knowledge, skills and attitudes necessary to become active and socially responsible citizens. Others may prioritize effective and constructive interaction within and between communities or pay more attention to the development of personal traits such as critical thinking (Eurydice, 2017). Thus, citizenship and citizen competencies in several areas have been re-defined and new dimensions to citizenship such as environmental/ecological citizenship, cultural citizenship, multi-cultural citizenship, minority citizenship, digital citizenship, active citizenship, economic citizenship, democratic citizenship, and constitutional citizenship have been put forward.

The expansion of perspective and meaning in the concept of citizenship has also necessitated taking those dimensions into consideration in measuring citizenship. Therefore, new scales for measuring the multi-dimensional structure of citizenship were developed (Erdem \& Koçyiğit, 2019; Beseler, et al., 2021; Çermik \& Akçay, 2020; Hadjichambis \& Paraskeva-Hadjichambi, 2020; Homer, 2020; İşman \& Güngören, 2014; Karatekin \& Uysal, 2018; Kim, \& Choi, 2018; Lo, et al., 2019; Şahin \& Çermik, 2014; Yazıcı et al., 2017; Yıldırım, 2018), all of which were included in the literature. Depicting the scales in the literature in general terms is important in understanding the attempts better at measuring citizenship. Hence, the present study aims to put the citizenship scales used in the Turkish literature in the area of social studies education to thematic content analysis. This research functions as a scientific resource where researchers studying in the field of citizenship education can see the scales developed/adapted on the subject. The results of this specific research also present a general picture of which dimensions and at which education level citizenship education is mostly studied. In other words, what dimensions of citizenship education are considered in more detail and what dimensions are considered in a limited manner can be seen by means of this study. In this regard, the study is thought to guide researchers in terms of including in the literature the required dimensions related to scales. In addition, the scales developed/adapted within the scope of citizenship education in the research are evaluated in terms of validity and reliability processes, so the present research also provides information about the compliance of the relevant scales with the scale development/adaptation standards.

Studies of thematic content analysis are capable of contributing to making knowledge widespread and shaping the future research studies in that they consider UpToDate studies in a holistic perspective and that they demonstrate the similarities and differences between studies (Braun \& Clarke, 2006; Çalık \& Sözbilir, 2014). Accordingly, analysing the scales developed or adapted in citizenship education through thematic content analysis contributes to the literature. The scales are evaluated in a critical perspective and efforts made to give a general picture of the weaknesses and strengths of the studies which used the scales. Therefore, it is 
expected to function as a scientific resource for researchers who plan to perform studies on citizenship education since it presents the current measurement instruments. In this way, it also provides researchers in the area of citizenship education with a resource in which the researchers can see the contemporary scales put together.

Review of relevant literature demonstrates that several studies have been conducted to examine the scale development/adaptation research. Some of these studies evaluate the compatibility of the stages followed with scale development/adaptation processes independently of the subjects and disciplines in which the scales are developed or adapted (Acar Güvendir \& Özer Özkan, 2015; Çüm \& Koç, 2013; Kaya Uyanık et al., 2017; Tavşancıl et al., 2014; Yurdabakan \& Çüm, 2017). Some other studies analyse the scale development/adaptation activities in certain disciplines such as mathematics and science (Delice \& Ergene, 2015; Ergene, 2020; Tosun \& Taşkesenligil, 2014), management and organisational behaviour (Kanten \& Arda, 2020) and music education (Çelik \& Yüksel, 2020). Some others, on the other hand, act more specifically and make a content analysis of the scales in a specific subject only. For instance, Chandu et al. (2020) analyse the measurement instruments about corona virus in more recent studies. Studies which consider the scales related to citizenship education with thematic content analysis, however, are not available in the literature. The study is therefore thought to be original in this sense.

\subsection{Research Questions}

This study aims to analyse the scales available in citizenship education in Turkey through thematic content analysis. In this sense, the problem sentence of the research is "How is the current situation regarding the scales developed/adapted within the scope of citizenship education in Turkey?" Based on this main problem, answers to the following sub-problems were sought in the study:

1. What is the distribution of the scales according to types of studies in which the scales are available?

2. What is the distribution of the scales according to years?

3. What is the distribution of the scales according to whether they are developed or adapted?

4. What are the key words used in the studies where the scales are available?

5. What is the distribution of the scales according to the stage of education for which validity and reliability tests were done?

6. What is the sample size used in the scales and is it enough when the number of items in the scale is considered?

7. What are the reliability estimating methods used in the scales?

8. What are the proofs of validity used in the scales?

9. What is the distribution of the scales according to the number of factors they have?

10. What is the distribution of the scales according to subjects?

\section{METHOD}

\subsection{The Research Model}

This research, which aims to examine the trends in scale development and adaptation studies in the field of citizenship education, is suitable for thematic content analysis. Several researchers emphasise that they do not consider thematic content analysis as a separate research method because it is a procedure employed in qualitative studies and that it should be considered as a technique which provides researchers with convenience (Nowell et al., 2017). Thematic content analysis is a qualitative research technique which involves describing, analysing and reporting the patterns in the data (themes) (Braun \& Clarke, 2006). The technique is quite useful in summarising or analysing the basic properties of large qualitative data sets (Nowell et al., 2017). Studies using thematic content analysis are important in that they provide researchers who study 
in relevant areas, who cannot reach all the studies in the area, and who cannot analyse them systematically with rich resources (Ültay \& Çalık, 2012).

\subsection{Data Collection}

The developed/adapted scales were reached by reviewing the national thesis data centre of the Council of Higher Education and by searching via Google scholar. No year limitation was applied during the browsing. The pages in Turkish were scanned by writing the Turkish key words "citizenship and scale*" on Google search engine in determining the scales to be analysed. All the probable results can be found by using the mark "**" at the end of the words while searching on Google. On searching by writing "scale*", for instance as in this study, both the word "scale in singular form" and its derivations "scales", "of the scale(s)", and "scale(s) in object position in sentences" can be accessed. Browsing was terminated on 17th January 2021. Therefore, the studies published after that date was excluded from the scope of this study.

After browsing the scales on Google scholar, the key words "scale" and "citizenship" were entered in the detailed search section on the national thesis centre database, the area of "social" was chosen and thus the scales were searched. The criteria for selecting the theses to be analysed were entered on the detailed search page of the thesis centre of the Council of Higher Education of Turkey, and thus the theses with scales developed or adapted in relation to citizenship education were included in the scope of this study. For the scale development/adaptation articles produced from the theses, only the thesis study in which the scale was published was taken into account during the scanning process. As a result, 56 scales in total which were developed or adapted were reached. All the studies mentioned are listed in Appendix-1.

\subsection{Data Analysis}

Content analysis technique was used in the evaluation of the data obtained in this study. The purpose of content analysis is to reach concepts and relationships that can explain the collected data. The data summarized and interpreted in descriptive analysis are subjected to a deeper processing in content analysis, and concepts and themes that cannot be noticed with a descriptive approach can be discovered as a result of this analysis. The basic process in content analysis is to gather similar data within the framework of certain concepts and themes and to organize and interpret them in a way that the reader can understand (Y1ldırım \& Şimşek, 2011). A checklist to help to analyse the scales used in citizenship education was created prior to the content analysis. The checklist aimed to set standard criteria for content analysis of the scales and consisted of two sections called "study tag" and "theoretical information". When we look at the content analysis studies in the literature (Kaya Uyanık et al., 2017; Taşdelen Teker \& Güler, 2019), it is seen that in the case of using a checklist, expert opinion is sought to determine the suitability of the checklist in terms of scope and content. From the point of this view, two experts of measurement and evaluation who studied scale development and scale adaptation were consulted for their opinions of the checklist. The experts recommended that measurement invariance, convergent validity, and divergent validity also be included in the heading of "validity and reliability evidence" as a label used in describing the studies analysed. Thus, the checklist was modified to include the suggestions (see Appendix-2). It has no criteria which can be interpreted differently by different individuals in the checklist. Therefore, coding by one expert was considered sufficient. While analysing the data it was found that the sample groups were described as university students in some of the scales whereas they were described as prospective teachers in some others. For this reason, in the study, the mentioned distinction was followed in the coding of the sample group. In addition, the statistical processes in testing the psychometric properties of the scales were categorised separately for scale development and scale adaptation studies because evidence provided for the validity and reliability can differ in scale development studies from the ones in scale adaptation studies. Frequency and percentage analyses of codes were calculated for each theme. 


\section{FINDINGS}

The type of studies in which the scales were published and their distributions according to years were checked in this study. The findings obtained are shown in Figure 1.

Figure 1. The distribution of the scales according to years and types of study.

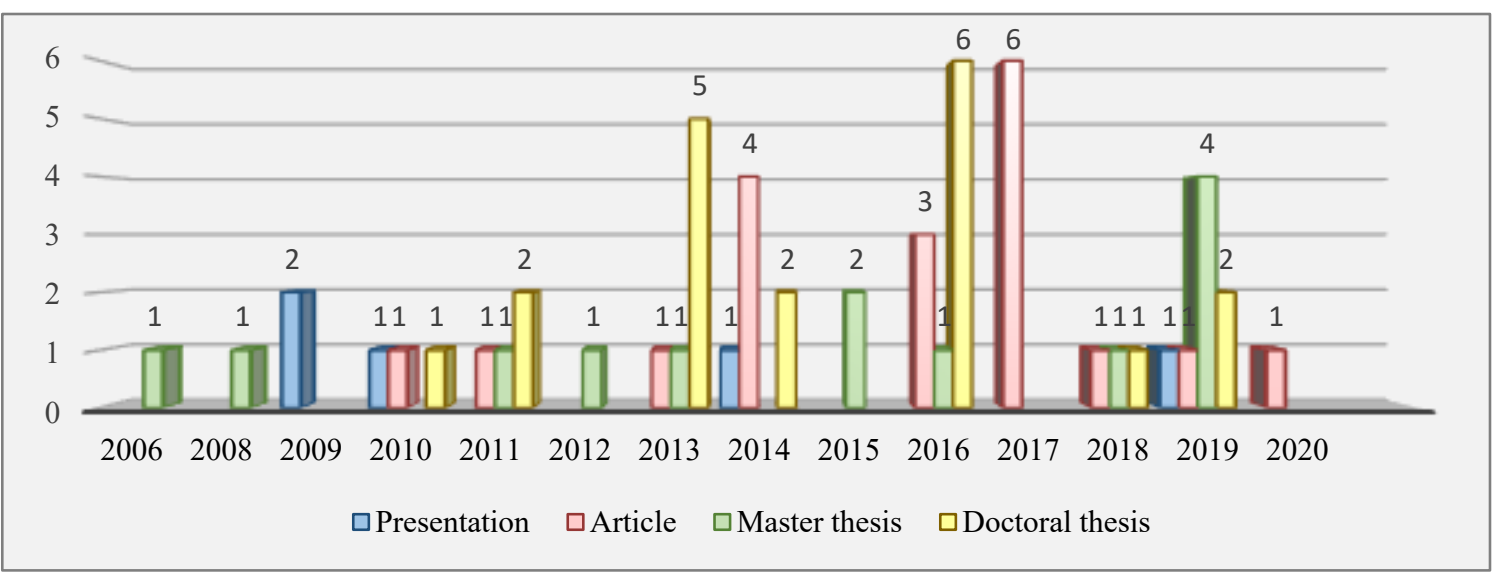

According to Figure 1, the studies in which citizenship scales were developed or adapted were mostly in the year 2016. There was only one study in 2006, 2008, 2012 and 2020 each. The majority of the scales of citizenship education were in doctoral theses and in articles. The number of M.A theses was smaller than the number of doctoral theses or of articles, and the number of conference presentations was much smaller. Having analysed the scales according to years and types of studies, they were analysed according to whether they were developed by researchers themselves or they were adapted from another culture. The findings in this respect are shown in Figure 2.

Figure 2. The distribution of the scales according to whether they were developed or adapted.

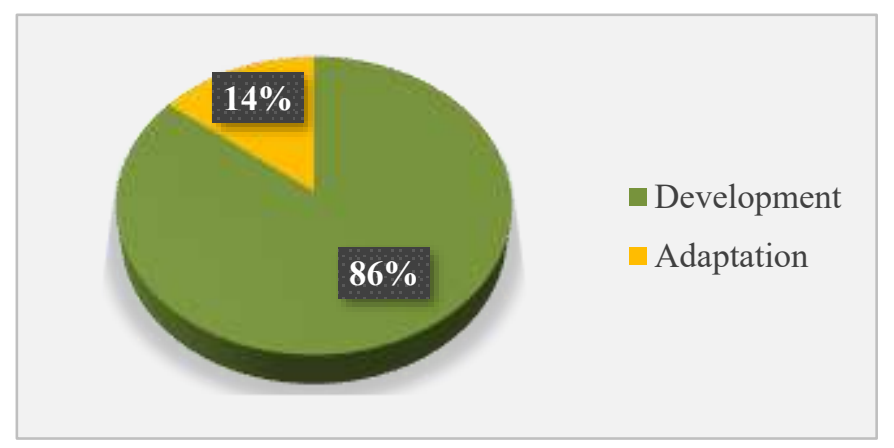

It is apparent from Figure 2 that the majority of the scales analysed (86\%) were developed by researchers themselves while the minority of them (14\%) were adapted into Turkish culture from other cultures. After that, the answer was sought to the question of "what key words were used in the studies analysed?" The frequency of the key words used in the studies in which the scales were available is shown in Table 1 . The frequencies for the key words were visualized through frequency questioning instead of tabulating them since the number of the key words was great. The size of the shapes obtained through word frequency questioning in Table 1 is directly proportionate to the frequency weight of the words. 
Table 1. The frequency questioning for the key words.

\begin{tabular}{lclc}
\hline Key Words & Frequency & Key Words & Frequency \\
\hline Citizenship & 21 & Secondary School & 3 \\
\hline Social Studies & 16 & Prospective Teachers & 3 \\
\hline Citizenship Education & 13 & Democracy & 3 \\
\hline Digital Citizenship & 7 & Democracy Education & 3 \\
\hline Social Studies Education & 6 & Citizen & 2 \\
\hline Peception of Citizenship & 4 & Democratic Citizenchip & 2 \\
\hline Global Citizenship & 4 & Active Citizenchip & 2 \\
\hline Effective Citizenchip & 4 & Socio-Scientific İssues & 2 \\
\hline Validity & 4 & Factor Analysis & 2 \\
\hline Reliability & 4 & Global Citizenship Education & 2 \\
\hline Scale Development & 4 & Social Media Citizenship Perception & 2 \\
\hline Teacher & 4 & Internet & 2 \\
\hline Effective Citizenship Self-Efficacy Scale & 3 & Citizenship Knowledge & 2 \\
\hline Globalization & 3 & Human Rights & 2 \\
\hline Global Citizen & 3 & Consciousness of Citizenship & 2 \\
\hline Values Education & 3 & Responsibility & 2 \\
\hline Character Education & 3 & The Other & 44 \\
\hline
\end{tabular}

According to Table 1, the most frequently used key words in the studies were citizenship, social studies, and citizenship education, followed by digital citizenship, social studies education, perception of citizenship, global citizenship, effective citizenchip, validity, reliability, scale development, and teacher. There are also 44 keywords with a frequency of 1 . After analysing the key words, the sampling stages and sample size were checked. It was determined that two of the scales published in the form of conference presentations were applied to secondary school students, two to prospective teachers and one to university students. Six of the scales published as article were applied to teacher candidates, five to secondary school students, five to university students, one to social studies teachers, and one to high school students. It was determined that 11 of the scales published within the scope of the thesis were applied to secondary school students, 10 to prospective teachers, four to university students, four to secondary school teachers, two to primary school students, one to high school students, and one to university students. The findings for the distribution of the studies according to sample size are shown in Table 2. 
Table 2. Findings for sample size and number of item in the scales.

\begin{tabular}{|c|c|c|c|c|c|c|c|}
\hline \multirow[b]{2}{*}{$\begin{array}{l}\text { Research } \\
\text { Id }\end{array}$} & \multicolumn{2}{|c|}{ Number of Item } & \multirow[b]{2}{*}{ Sample Size } & \multirow[b]{2}{*}{$\begin{array}{c}\text { Research } \\
\text { Id }\end{array}$} & \multicolumn{2}{|c|}{ Number of Item } & \multirow[b]{2}{*}{$\begin{array}{c}\text { Sample } \\
\text { Size }\end{array}$} \\
\hline & $\begin{array}{l}\text { Initial } \\
\text { form }\end{array}$ & $\begin{array}{l}\text { Last } \\
\text { form }\end{array}$ & & & $\begin{array}{l}\text { Initial } \\
\text { form }^{*}\end{array}$ & $\begin{array}{l}\text { Last } \\
\text { form }\end{array}$ & \\
\hline 1 & 43 & 18 & 392 & 29 & & 55 & 710 \\
\hline 2 & & 73 & 414 & 30 & & 43 & 786 \\
\hline 3 & & 18 & 635 & 31 & 29 & 29 & 291 \\
\hline 4 & 45 & 27 & 480 & 32 & 29 & 29 & 291 \\
\hline 5 & 41 & 28 & 150 & 33 & 22 & 14 & 432 \\
\hline 6 & 45 & 29 & 374 & 34 & & 35 & 100 \\
\hline 7 & 59 & 29 & 272 & 35 & 24 & 13 & 623 \\
\hline 8 & 28 & 18 & 229 & 36 & & 5 & 116 \\
\hline 9 & & 34 & 1063 & 37 & 51 & 16 & 635 \\
\hline 10 & 120 & 67 & 625 & 38 & & 20 & 494 \\
\hline 11 & 80 & 32 & 480 & 39 & & 28 & 238 \\
\hline 12 & 13 & 11 & 241 & 40 & 64 & 45 & 500 \\
\hline 13 & 31 & 27 & 180 & 41 & 45 & 38 & 672 \\
\hline 14 & 44 & 24 & 532 & 42 & 41 & 20 & 1028 \\
\hline 15 & 74 & 48 & 311 & 43 & 46 & 25 & 503 \\
\hline 16 & 24 & 23 & 317 & 44 & 53 & 38 & 2190 \\
\hline 17 & & 21 & 400 & 45 & 10 & 10 & 250 \\
\hline 18 & 145 & 87 & 2144 & 46 & & 28 & 1099 \\
\hline 19 & 42 & 25 & 544 & 47 & 35 & 35 & 185 \\
\hline 20 & 63 & 49 & 438 & 48 & 23 & 21 & 295 \\
\hline 21 & 65 & 33 & 670 & 49 & 40 & 15 & 200 \\
\hline 22 & & 25 & 297 & 50 & 40 & 23 & 100 \\
\hline 23 & & 30 & 241 & 51 & & 84 & 150 \\
\hline 24 & 42 & 18 & 288 & 52 & & 20 & 1467 \\
\hline 25 & & 30 & 429 & 53 & 36 & 29 & 323 \\
\hline 26 & 56 & 33 & 183 & 54 & 11 & 10 & 323 \\
\hline 27 & 51 & 20 & 249 & 55 & 9 & 7 & 323 \\
\hline 28 & 84 & 57 & 352 & 56 & & 25 & 552 \\
\hline
\end{tabular}

*While the initial form includes the number of items included in factor analyses and the last form includes the number of items in the scale as a result of factor analyses.

According to Table 2, the most frequently used sample size in the studies analysed were between 201 and 300 participants. In addition, the sample size of eight out of 56 studies was less than five times the number of items in the initial form. The number of factors was focused on after analysing the sample size. Figure 3 shows the findings.

Figure 3. The distribution of the number of factors in the scales.

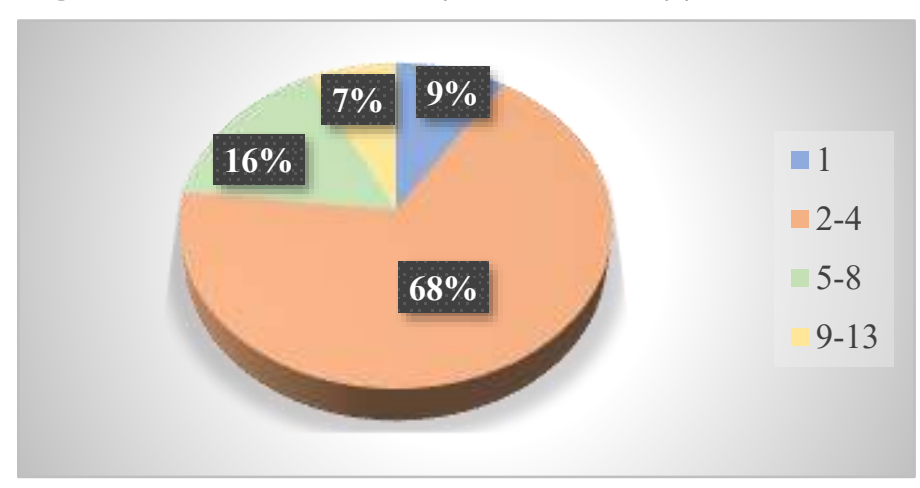


It is apparent from Figure 3 that the number of scales with one factor is limited (only 9\%). Most of the scales (68\%) have 2-4 factors. The scales with 5-8 factors and those with 8-13 factors are also few. Table 3 below shows the distribution of the scales according to their subject matter.

Table 3. The distribution of the scales of citizenship education according to their subject matter.

\begin{tabular}{|c|c|c|c|c|c|c|c|}
\hline & $\begin{array}{l}\text { Primary } \\
\text { School }\end{array}$ & $f \begin{array}{l}\text { Secondary } \\
\text { School }\end{array}$ & $f$ High School & $f \begin{array}{l}\text { University } \\
\text { Students }\end{array}$ & $f \begin{array}{l}\text { Prospective } \\
\text { Teachers }\end{array}$ & $f \begin{array}{l}\text { Teachers of } \\
\text { Social Studies }\end{array}$ & $f$ \\
\hline \multirow{2}{*}{ 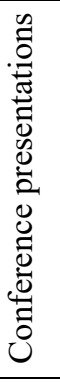 } & & $\begin{array}{l}\text { Knowledge of } \\
\text { citizenship }\end{array}$ & 1 & $\begin{array}{l}\text { Global } \\
\text { citizenship }\end{array}$ & $\begin{array}{l}1 \text { Active } \\
\text { citizenship }\end{array}$ & 1 & \\
\hline & & $\begin{array}{l}\text { Perceptions of } \\
\text { citizenship }\end{array}$ & 1 & & $\begin{array}{l}\text { Citizenship } \\
\text { competencies }\end{array}$ & 1 & \\
\hline \multirow{4}{*}{$\stackrel{\frac{0}{0}}{\stackrel{0}{2}}$} & & Citizenship skills & $\begin{array}{l}1 \text { Feelings of } \\
\text { citizenship }\end{array}$ & $\begin{array}{l}1 \text { Digital } \\
\text { citizenship }\end{array}$ & $\begin{array}{l}2 \text { Global } \\
\text { citizenship }\end{array}$ & 3 & \\
\hline & & $\begin{array}{l}\text { Attitudes } \\
\text { towards } \\
\text { citizenship } \\
\text { education }\end{array}$ & $\begin{array}{l}2 \text { Perceptions } \\
\text { of good } \\
\text { citizenship }\end{array}$ & $\begin{array}{l}1 \text { Global } \\
\text { citizenship }\end{array}$ & $\begin{array}{l}1 \text { Ecological } \\
\text { citizenship }\end{array}$ & $\begin{array}{l}1 \text { Ideology of } \\
\text { citizenship } \\
\text { education }\end{array}$ & 1 \\
\hline & & $\begin{array}{l}\text { Digital } \\
\text { citizenship }\end{array}$ & 1 & $\begin{array}{l}\text { Active } \\
\text { citizenship }\end{array}$ & $\begin{array}{l}2 \text { Effective } \\
\text { citizenship }\end{array}$ & 1 & \\
\hline & & $\begin{array}{l}\text { Effective } \\
\text { citizenship }\end{array}$ & 1 & & $\begin{array}{l}\text { Digital } \\
\text { citizenship }\end{array}$ & 1 & \\
\hline \multirow{8}{*}{ 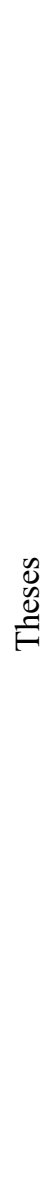 } & $\begin{array}{l}\text { Active } \\
\text { citizenship }\end{array}$ & $\begin{array}{l}1 \text { Attitudes } \\
\text { towards the } \\
\text { citixenship and } \\
\text { Democracy } \\
\text { education course }\end{array}$ & $\begin{array}{l}4 \text { Democratic } \\
\text { citizenship }\end{array}$ & $\begin{array}{l}1 \text { Perceptions of } \\
\text { citizenship on } \\
\text { social media }\end{array}$ & $\begin{array}{l}1 \text { Good } \\
\text { citizenship }\end{array}$ & $\begin{array}{l}1 \text { Digital } \\
\text { citizenship }\end{array}$ & 1 \\
\hline & $\begin{array}{l}\text { Global } \\
\text { citizenship }\end{array}$ & $\begin{array}{l}1 \text { Perceptions of } \\
\text { citizenship }\end{array}$ & 2 & $\begin{array}{l}\text { Perceptions of } \\
\text { citizenship }\end{array}$ & $\begin{array}{l}2 \text { Perceptions of } \\
\text { citizenship }\end{array}$ & $\begin{array}{l}1 \text { Perceptions of } \\
\text { the goals of } \\
\text { citizenship } \\
\text { course }\end{array}$ & 1 \\
\hline & & $\begin{array}{l}\text { Citizenship } \\
\text { consciousness }\end{array}$ & 2 & $\begin{array}{l}\text { Citizenship } \\
\text { competencies }\end{array}$ & $\begin{array}{l}1 \text { Attitudes } \\
\text { towards } \\
\text { patriotism }\end{array}$ & $\begin{array}{l}1 \text { Perceptions of } \\
\text { the activities } \\
\text { in citizenship } \\
\text { course }\end{array}$ & 1 \\
\hline & & $\begin{array}{l}\text { Ecological } \\
\text { citizenship }\end{array}$ & 1 & $\begin{array}{l}\text { Digital } \\
\text { citizenship }\end{array}$ & $\begin{array}{l}1 \text { Types of } \\
\text { citizenship }\end{array}$ & $\begin{array}{l}1 \text { Perceptions of } \\
\text { the teaching } \\
\text { quality in } \\
\text { citizenship } \\
\text { course }\end{array}$ & 1 \\
\hline & & $\begin{array}{l}\text { Global } \\
\text { citizenship }\end{array}$ & 1 & & $\begin{array}{l}\text { Global } \\
\text { citizenship }\end{array}$ & 1 & \\
\hline & & $\begin{array}{l}\text { Digital } \\
\text { citizenship }\end{array}$ & 1 & & $\begin{array}{l}\text { Active } \\
\text { citizenship }\end{array}$ & 2 & \\
\hline & & & & & $\begin{array}{l}\text { Effective } \\
\text { citizenship }\end{array}$ & 1 & \\
\hline & & & & & $\begin{array}{l}\text { Digital } \\
\text { citizenship }\end{array}$ & 1 & \\
\hline
\end{tabular}


According to Table 3, the scales used in citizenship education centre around global citizenship, digital citizenship, effective citizenship, and active citizenship. There are limited number of instruments to measure ecological citizenship. Besides, it was also found that the scales for determining the attitudes towards the citizenship education course, perceptions of good citizenship and of the concept of patriotism, citizenship consciousness, knowledge of citizenship, and citizenship competencies were developed or adapted. Finally, the reported validity and reliability evidence was checked. The findings are shown in Table 4 by taking scale development and scale adaptation into consideration.

Table 4. The number of validity/reliability evidence reported in the scales of citizenship education.

\begin{tabular}{|c|c|c|c|c|}
\hline & & & Developed & Adapted \\
\hline \multirow{12}{*}{ 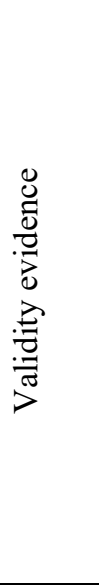 } & \multirow{8}{*}{ Construct } & Confirmatory factor analysis (CFA) only & 0 & 4 \\
\hline & & Exploratory factor analysis (EFA) only & 27 & 2 \\
\hline & & Both CFA and EFA & 18 & 2 \\
\hline & & Convergent-divergent validity & 0 & 0 \\
\hline & & Known groups validity & 0 & 0 \\
\hline & & Criterion related validity & 1 & 1 \\
\hline & & Measurement invariance & 0 & 0 \\
\hline & & Unreported & 3 & 0 \\
\hline & \multirow{3}{*}{ Content } & Expert opinion & 40 & - \\
\hline & & Content validity rate index & 0 & - \\
\hline & & Unreported & 8 & - \\
\hline & No validity & evidence was reported & 1 & 0 \\
\hline \multirow{4}{*}{ 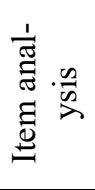 } & \multicolumn{2}{|c|}{ Only lower-upper groups were compared } & 6 & 0 \\
\hline & \multicolumn{2}{|c|}{ Only item-test correlations } & 8 & 5 \\
\hline & \multicolumn{2}{|c|}{ Both lower-upper groups compared and item-test correlations } & 8 & 0 \\
\hline & \multicolumn{2}{|c|}{ Unreported } & 26 & 3 \\
\hline \multirow{5}{*}{ 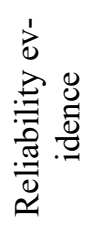 } & \multicolumn{2}{|c|}{ Only Cronbach's Alpha } & 48 & 8 \\
\hline & \multicolumn{2}{|c|}{ Test-retest method } & 5 & 1 \\
\hline & \multicolumn{2}{|c|}{ Parallel forms method } & 2 & 0 \\
\hline & \multicolumn{2}{|c|}{ Split half reliability (Spearman Brown and Guttman) } & 7 & 1 \\
\hline & \multicolumn{2}{|c|}{ No reliability evidence was reported } & 0 & 0 \\
\hline
\end{tabular}

As evident from Table 4, only CFA was used in four out of eight scale adaptation studies whereas both EFA and CFA were used in two studies and only EFA was used in two studies. It was found on analysing the scales adapted in terms of item analysis that five out of eight scales did item analysis but that the remaining three scales did not do item analysis. Item-test correlation was calculated in all of the five scales in which item analysis was done. Besides, it was also found that Cronbach's Alpha internal consistency coefficient was used so as to estimate the reliability of the measurements in all the adaptation studies. Test-retest and split half reliability was also calculated in addition to internal consistency reliability in one of the scales.

According to Table 4, only EFA was done for construct validity in scale development studies mostly EFA and CFA were used in combination in a considerable number of studies. There were no scale development studies in which only CFA was used In one of the studies, however, criterion related validity was calculated in addition to EFA and CFA. The number of studies that offered no statistical evidence for construct validity was three.

Expert opinion was consulted for content validity in 40 out of 48 scale development studies. Content validity rate index was not calculated in any of them. Thus, no evidence was provided for content validity in eight of the studies. No evidence was provided for validity in one of the 
studies. Convergent validity, divergent validity, known groups validity, or measurement invariance were not tested in any of the scale development studies as in the case in adaptation studies. On revising the scale development studies in terms of item analysis, only lower groupupper group comparison was looked at in six studies, only item-test correlations were looked at in eight studies and both the lower group-upper group comparison and item-test correlations were looked at in eight studies. On the other hand, no statistical findings were found in 26 studies.

Cronbach's Alpha internal consistency reliability was calculated in all of the scale development studies as in scale adaptation studies. Split half reliability beside Cronbach's Alpha internal consistency coefficient was reported in seven of the studies. It was found that test-retest reliability was calculated in one of the seven studies and that test-retest reliability and parallel forms reliability were calculated in one of the seven studies. Besides, it was also found that the only reliability evidence provided apart from Cronbach's Alpha was test-retest coefficient. In one of the studies, on the other hand, test-retest reliability and parallel forms reliability in addition to Cronbach's Alpha were checked.

\section{DISCUSSION and CONCLUSION}

In this study, the scales developed or adapted for citizenship education in Turkey were put to thematic content analysis with no limitation on the year when they were developed or adapted. Thus, 56 scale development/adaptation studies in total were analysed in the research. The analyses demonstrated that the studies were conducted mostly in the year 2016. In terms of years, it can be said that there has been an increase in the number of studies towards the present. The majority of the scales were developed/adapted in doctoral theses and articles, while only a few of them were published in MA theses and in conference presentations. It is necessary to work with relatively large samples and to follow a multi-stage process in scale development/adaptation studies. This situation can be considered as the reason why researchers do not engage in such a process much in their master's theses and conference presentations. That is, when they consider the effort they put into collecting and analyzing the data, many researchers tend to publish their studies as an article instead of concluding their efforts with a conference presentation. In addition, the time needed for the scale development and adaptation processes may cause time anxiety for researchers writing master's thesis. Since doctoral theses are spread over a longer period compared to master's theses, researchers may experience less temporal anxiety about undertaking the scale development/adaptation process. In addition, researchers writing a master's thesis may be reluctant to engage in the scale development/adaptation process due to their lack of knowledge/experience and being at the beginning of the road. These listed factors can be considered as the reasons why scale development/adaptation processes are heavily used in doctoral theses, but not so often in master's theses.

Secondly, it was concluded that the majority of scales were developed and only a few of them were adapted to Turkish culture. Citizenship is a dynamic structure and the meaning attributed to the concept of citizenship can also differ from society to society (Schugurensky, 2005). For example, military service in Iceland is not a civic duty, whereas in Israel, military service is one of the basic duties for all citizens, regardless of whether they are men or women. In Turkey, military service is defined as a duty for every male citizen who does not have a health problem. This structure of citizenship, which changes from society to society and which is open to being affected by cultural elements, may have led researchers to scale development studies instead of adapting measurement tools developed in different cultures into Turkish. 
When the keywords used in the studies in which the scales were examined, it was determined that the words "citizenship", "social studies", and "citizenship education" were mostly used. Such a result is not surprising, considering the fact that a search was made with the expression of citizenship while determining the studies to be examined in the research. In this sense, the result that is more striking about the keywords and that needs to be interpreted more is that the subject area in which the scales are developed is frequently included in the keywords. For example, the keywords of digital citizenship, global citizenship, and citizenship perception were used more frequently.

Considering the preferred sample level in the scales, it was concluded that the most frequently studied group is university students (pre-service teachers and students studying in other faculties). University students are generally a more accessible sample for researchers. Therefore, researchers may prefer to study on university students rather than studying at other educational levels. It is thought that individuals' understanding of citizenship is shaped in early adulthood because the first thing that comes to mind when the citizen is mentioned is usually the adult person. Being young, on the other hand, corresponds to a transition/becoming rather than a state and is somewhere between a child and an adult. Therefore, in this early adulthood, the individual learns citizenship through certain experiences (Kalaycıoğlu \& Çelik, 2008). The fact that individuals' understanding of citizenship is only fully shaped in their first adulthood may be another reason for the scales being developed/adapted mostly on university students. When the studies were examined according to the sample sizes, it was determined that the scale development and adaptation studies were mostly carried out with research groups containing 201-300 participants. In other words, researchers may have preferred sample sizes between 200 and 300, with the thought of being sufficient for validity and reliability analyses on the one hand, and being economical on the other. Furthermore, the sample size of eight out of 56 studies was less than five times the number of items in the initial form. Researchers have made different suggestions about the number of participants that should be included in factor analysis studies. Cattell (1978) recommends that three to six times the number of items in the scale be included in the study group in factor analysis studies and states that 200 participants are acceptable for factor analysis and 500 participants is a very good number. Gorsuch (1983) recommends that there be at least five participants in the study group for each item in the scale in factor analysis studies, however, he states that the number of participants should not be less than 100 (Cramer, 2003). These suggested criteria for sample size may be a reference for researchers. As a result, it can be said that in most of the studies, the sample size selection was determined to be five times the number of items.

Another result of the research is related to the number of factors in the examined scales. While a single factor structure was observed in a very small part of the scales, a multidimensional structure consisting of at least two factors was revealed in most of the scales. This result can be interpreted as a reflection of the transformation of citizenship into a comprehensive concept that includes many dimensions.

When the scales subject to the research were examined in terms of validity evidence, it was determined that EFA was applied in almost all of the scale development studies. EFA is an exploratory analysis to reveal the structure observed in the scale. Since there is no empirical dimensioning in scale development studies, it is expected that EFA will be applied in almost all of these studies. In a substantial part of the scale development studies, CFA was performed together with EFA Since it is not possible to reach definite results in social sciences as in science, it is important to support the results obtained with more than one evidence. It is estimated that the use of CFA together with EFA in studies stems from this idea.

When we look at the scale adaptation studies, it can be seen that the rate of research that does not include EFA and only applied CFA is higher than that of scale development. In scale 
adaptation studies, there is a measurement tool that was previously developed in another culture, that is, the factor structure was empirically revealed. In other words, in adaptation studies, it is questioned whether the factor structure in the culture in which the scale was developed is also valid for a certain target culture. In this respect, it is a reasonable result that only CFA was applied in most of the scale adaptation studies. Convergent-divergent validity and measurement invariance were not tested in any of the scale development/adaptation studies. This result can be attributed to the competence levels of the researchers who developed/adapted the scales in the field of measurement and evaluation. Indeed, when the related literature is reviewed, it is seen that almost all of the studies on measurement invariance in Turkey belong to researchers in the field of measurement and evaluation. This situation observed in measurement invariance also shows itself in convergent-divergent validity studies. The fact that criterion-related validity was included in only one study can be explained by the difficulty in the data collection process because this type of validity requires the application of another measurement tool related to the subject of the scale, along with the scale that is aimed to be developed/adapted to the participants. This can complicate the data collection process and make it difficult for researchers to test criterion-related validity.

In most of the scale development studies examined in the research, expert opinion was sought in order to make a judgment about the content validity. The assessment of content validity relies on using a panel of experts to evaluate instrument items and rate them based on their relevance and representativeness to the content domain. It is recommended to use the statistics such as percent agreement and modified Kappa in order to obtain a Content Validity Index (CVI) based on expert judgements. Content validity indices are essential factors in the instrument development process and should be treated and reported as important as other types of construct validation (Almanasreh, et al, 2019). However, no study has reported the content validity index based on expert opinions. More clearly, the evidence presented for content validity remained at the qualitative level, but was not converted into a quantitative value. In some of the studies, no information was given about the processes to ensure content validity. However, no matter how well the researcher has reviewed the literature and prepared the items carefully, he/she should seek the opinions of experts in order to ensure the content validity of the measurement tool he/she has created and preferably make these views more concrete by calculating the content validity index.

Considering the reliability evidences, it was seen that the Cronbach alpha internal consistency coefficient was calculated in all of the scale development and adaptation studies. This result is in line with the conclusions of the study in which Acar Güvendir and Özer Özkan (2015) examined the articles on scale development and adaptation in the field of educational sciences and the studies in which Şahin and Boztunç Öztürk (2018) subjected the scale development studies in the field of education to content analysis. The number of studies in which parallel form and test-retest reliability were calculated is very limited. This result can be associated with Cronbach's alpha being a more useful reliability determination method for researchers. More clearrly, Cronbach's alpha is a reliability estimation method based on a single application. On the other hand, test-retest reliability requires applying the scale to the same group twice with a certain time interval. Again, in the parallel form method the reliability coeffeicient is estimated by administering another measurement tool that measures the same construct as the scale developed/adapted by the researcher to the same sample group (Boztunç Öztürk \& Şahin, 2021). It can be stated that the necessity of two different applications leads to the use of testretest and parallel form reliability less frequently.

Another remarkable result regarding reliability is that in addition to Cronbach's alpha, split-half reliability is reported in some measurement tools. Like Cronbach's alpha, split-half reliability is a useful method of determining internal consistency. The average of all possible split-half 
reliability values that can be calculated for a measurement tool is identical to the Cronbach's alpha internal consistency coefficient if two halves are equal (Warrens, 2015). In this sense, while Cronbach's alpha has already been reported, the calculation of the split-half reliability does not provide more information about the internal consistency of the measurements. Reporting Cronbach's alpha and split-half reliability together shows that this situation can be ignored by the researchers.

According to the examinations on item analysis, it was understood that in about half of the scale development and adaptation studies, no analysis for item discrimination was included. The fact that item discrimination indices are generally parallel to factor loads obtained from factor analysis can be considered as the reason for this situation. However, it is important not to be satisfied with factor analysis and to calculate item discrimination in order to provide more evidence about the validity of the items. In the study, coding was done by a single researcher. Although the researcher performed the coding twice in different time intervals for reliability, the fact that the coding was done by a single researcher can be seen as a limitation of this research. In this sense, the codings should be done at least by two researchers for supporting the reliability of the results in such studies with two or more authors.

\section{Declaration of Conflicting Interests and Ethics}

The authors declare no conflict of interest This research study complies with research publishing ethics The scientific and legal responsibility for manuscripts published in IJATE belongs to the authors

\section{Authorship Contribution Statement}

Melehat Gezer: Investigation, Resources, Visualization, Formal Analysis, Writing original draft, Methodology, and Validation.

\section{Orcid}

Melehat Gezer [D https://orcid.org/0000-0001-7701-3203

\section{REFERENCES}

Acar Güvendir, M., \& Özer Özkan, Y. (2015). Türkiye'deki eğitim alanında yayımlanan bilimsel dergilerde ölçek geliştirme ve uyarlama konulu makalelerin incelenmesi [The examination of scale development and scale adaptation articles published in Turkish academic journals on education]. Electronic Journal of Social Sciences, 14(52), 23-33. https://doiorg/1017755/esosder54872

Almanasreh, E., Moles, R., \& Chen, T.F. (2019). Evaluation of methods used for estimating content validity. Research in Social and Administrative Pharmacy, 15(2), 214-221. https://doiorg/101016/jsapharm201803066

Beseler, C.L., Jones, L.M., \& Mitchell, K.J. (2021). Measuring online prosocial behaviors in primary school children: Psychometric properties of the online civility scale. Contemporary School Psychology. https://doiorg/101007/s40688-021-00401-5

Boztunç Öztürk, N., \& Şahin, M.G. (2021). Bilimsel araştırmaya temel oluşturan ölçme kavramları [Measurement concepts that form the basis of scientific research]. In B. Çetin, M. İlhan, \& M. G. Şahin, (Eds.), Ë̆itimde araştırma yöntemleri [Research methods in education], (pp 1-34). Pegem.

Braun, V., \& Clarke, V. (2006). Using thematic analysis in psychology. Qualitative Research Psychology, 3(2), 77-101. Retrieved from https://wwwtandfonlinecom/doi/abs/101191/1 478088706qp063oa

Cattell, R.B. (1978). The scientific use offactor analysis in behavioral and life sciences. Plenum 
Chandu V.C., Marella Y., Panga, G.S., Pachava, S., \& Vadapalli, V. (2020). Measuring the impact of COVID-19 on mental health: A scoping review of the existing scales. Indian $J$ Psychol Med, 42(5), 421-427. https://doiorg/101177\%2F0253717620946439

Cramer, D. (2003). Advanced Quantitative Data Analysis. McGraw Hill Education.

Çalık, M., Ayas, A., \& Ebenezer, J. V. (2005). A review of solution chemistry studies: Insights into students' conceptions. Journal of Science Education and Technology, 14(1), 29-50. Retrieved from: https://linkspringercom/article/101007/s10956-005-2732-3

Çalık, M., \& Sözbilir, M. (2014). Parameters of content analysis. Education and Science, 39(174), 33-38. https://doiorg/1015390/EB20143412

Çelik, D., \& Yüksel, G. (2020). Müzik eğitimi kapsamında yapılan ölçek geliştirme çalışmalarının çok yönlü incelenmesi [Versatile analysis of scale development studies conducted within the scope of music education]. Journal of the Human and Social Science Researches, 9(5), 4059-4087. https://doiorg/1015869/itobiad793488

Çermik, E., \& Akçay, B. (2020). Çevresel vatandaşlık bilgi testinin geliştirilmesi ve ortaokul öğrencilerinin bilgi düzeylerinin belirlenmesi [Developing environmental citizenship knowledge test and determining the knowledge levels of secondary school students]. Turkish Studies - Education, 15(2), 731-750. https://dxdoiorg/1029228/TurkishStudies4 2112

Çüm, S., \& Koç, N. (2013). Türkiye'de psikoloji ve eğitim bilimleri dergilerinde yayımlanan ölçek geliştirme ve uyarlama çalışmalarının incelenmesi [The review of scale development and adaptation studies which have been published in psychology and education journals in Turkey]. Education Science and Practice, 12(24), 115-135.

Delice, A., \& Ergene, Ö. (2015). Investigation of scale development and adaptation studies: an example of mathematics education articles. Karaelmas Journal of Educational Sciences, 3(1), 60-75. Retrieved from https://dergiparkorgtr/en/download/article-file/2160898

Erdem, C., \& Koçyiğit, M. (2019, April 25-28). Adapting the digital citizenship scale to Turkish: validity and reliability study [Conference presentation abstract]. 28th International Conference on Educational Sciences (ICES 2019), Ankara, Turkey.

Ergene, Ö. (2020). Matematik eğitimi alanında ölçek geliştirme ve ölçek uyarlama makaleleri: betimsel içerik analizi [Scale development and adaptation articles in the field of mathematics education: descriptive content analysis]. Journal of Education for Life, 34(2), 360-383. https://doiorg/1033308/266748742020342207

Eurydice (European Commission/EACEA/) (2012). Citizenship education in Europe. Author.

Eurydice (European Commission/EACEA/) (2017). Citizenship education at school in Europe - 2017 Eurydice Report. Publications Office of the European Union.

Gezer, M. (2020). Ortaokul öğrencilerinin perspektifinden iyi insan iyi vatandaş [Good human good citizen from the perspective of secondary school students]. Çukurova University Faculty of Education Journal, 49(2), 995-1024. https://doiorg/1014812/cufej673422

Hadjichambis, A.C., \& Paraskeva-Hadjichambi, D. (2021). Environmental citizenship questionnaire (ECQ): The development and validation of an evaluation instrument for secondary school students. Sustainability, 12(3), 821-833. https://doiorg/103390/su1203 $\underline{0821}$

Homer, S. T. (2020, Jul 4-5). Perceived corporate citizenship: A scale development and validation study adopting a bottom-up approach [Conference full text]. 2 International European Conference on Interdisciplinary Scientific Researches Full Text Book, pp 431440.

İşman, A., \& Güngören, Ö. C. (2014). Dijital vatandaşlık [Digital citizenship]. TOJET: The Turkish Online Journal of Educational Technology, 13(1), 73-77. Retrieved from http://wwwtojetnet/articles/v13i1/1317pdf 
Kalaycıoğlu, S., \& Çelik, K. (2008). Genç insanın vatandaş olma ve tanınma hakkı [Young Person's Right to Become Citizen and to be Recognized]. Insan Haklarl Yıllığı, 26, 4157. Retrieved from https://dergiparkorgtr/tr/pub/ihy/issue/61998/928117

Kanten, P., \& Arda, B. (2020). Yönetim ve örgütsel davranış yazınındaki ölçek geliştirme çalışmalarının metodolojik açıdan analizi [The methodological analysis of scale development studies in management and organizational behavior fields]. Business and Economics Research Journal, 11(2), 581-590. https://doiorg/1020409/berj2020269

Karatekin, K., \& Uysal, C. (2018). Ekolojik vatandaşlık ölçeği geliştirme çalışması [Ecological citizenship scale development study]. International Electronic Journal of Environmental Education, 8(2), 82-104.

Kaya Uyanık, G., Güler, N., Taşdelen Teker, G., \& Demir, S. (2017). Türkiye'de eğitim alanında yayımlanan ölçek geliştirme çalışmalarının uygunluğunun çok yüzeyli rasch modeli ile incelenmesi [Investigation of scale development studies conducted in educational sciences published in Turkey by many-faceted rasch model]. Journal of Measurement and Evaluation in Education and Psychology, 8(2), 183-199. https://doiorg/1021031/epod291367

Kerr, D. (1999). Citizenship education in the curriculum: An international review. The School Field: International Journal of Theory and Research in Education, 10(3/4), 5-31. Retrieved from http://citeseerxistpsuedu/viewdoc/summary?doi=10115852377

Kim, M., \& Choi, D. (2018). Development of youth digital citizenship scale and implication for educational setting. Educational Technology \& Society, 21(1), 155-171. Retrieved from https://wwwjstororg/stable/26273877?seq=1\#metadata info tab contents

Lo, K.W.K., Kwan, K.P., Ngai, G., \& Chan, S.C.F. (2019, January 10-12). Cross-cultural validation of the global citizenship scale for measuring impacts of international servicelearning in Hong Kong setting [Paper presentation]. The 3rd International Conference on Service-Learning, Hong Kong.

Loobuyck, P. (2021). The policy shift towards citizenship education in Flanders How can it be explained?. Journal of Curriculum Studies, 53(1), 65-82. https://doiorg/101080/002202 7220201820081

Nowell, L.S., Norris, J.M., White, D.M., \& Moules, N.J. (2017). Thematic Analysis: Striving to meet the trustworthiness criteria. International Journal of Qualitative Methods, 16, 113. https://doiorg/101177\%2F1609406917733847

Özel, S. (2007). Küreselleşme döneminde vatandaşllk. Retrieved from http://wwwanayasagov tr/files/pdf/anayasa yargisi/soli ozelpdf

Schugurensky, D. (2005). Citizenship and citizenship education: Canada in an international context. Text prepared as input for discussion for the course AEC3131 ON.

Şahin, İ.F., \& Çermik, F. (2014). Küresel vatandaşlık ölçeğinin Türkçeye uyarlanması: Güvenirlik ve geçerlik çalışması [Turkish adaptation of global citizenship scale: Reliability and validity]. Eastern Geographical Review, 31, 207-218. https://doiorg/1017295/dcd30443

Şahin, M.G., \& Boztunç Öztürk, N. (2018). Eğitim alanında ölçek geliştirme süreci: Bir içerik analizi çalışması [Scale development process in educational field: a content analysis research]. Kastamonu Education Journal, 26(1), 191-199. https://doi:1024106/kefdergi3 75863

Şahin, M., Şahin, S., \& Göğebakan Yıldız, D. (2016). Sosyal bilgiler eğitimi programı ve dünya vatandaşlığı: Öğretmen adaylarının perspektifinden [The curriculum of social studies education and World citizenship: From perspective of prospective teachers]. Hacettepe University Journal of Education, 31(2), 369-390. http://dxdoiorg/1016986/HUJE201601 $\underline{5386}$ 
Taşdelen Teker, G., \& Güler, N. (2019). Thematic content analysis of studies using generalizability theory. International Journal of Assessment Tools in Education, 6(2), 279-299. http://dxdoiorg/1021449/ijate569996

Tavşanc1l, E., Güler, G., \& Ayan, C. (2014, Jun 9-13). Review of attitude scales developed in Turkey between 2002 and 2012 regarding scale developing process [Conference presentation abstract]. 4th Congress on Measurement and Evaluation in Education and Psychology (EPOD 2014), Ankara, Turkey.

Tosun, C., \& Taşkesenligil, Y. (2014, Sep 11-14). Document analysis of scales and achievement tests developed/adapted in the field of science education in Turkey [Conference presentation abstract]. XI National Science and Mathematics Education Congress, Adana, Turkey.

Warrens, M.J. (2015). On Cronbach's alpha as the mean of all split-half reliabilities. Quantitative Psychology Research, 89, 293-300. https://doiorg/101007/978-3-31907503-7 18

Ültay, N., \& Çalık, M. (2012). A thematic review of studies into the effectiveness of contextbased chemistry curricula. Journal of Science Education and Technology, 26(6), 686701. https://doiorg/101007/s10956-011-9357-5

Yazıcı, S., Arslan, H., Çetin, E., \& Dil, K. (2017). Aktif yurttaşlık ölçme aracının geliştirilmesi üzerine bir çalışma [A study on the development of active citizen questionnaire]. International Periodical for the Languages, Literature and History of Turkish or Turkic, 12(13), 1-22. http://dxdoiorg/107827/TurkishStudies11645

Yurdabakan, İ., \& Çüm, S. (2017). Davranış bilimlerinde ölçek geliştirme (Açıklayıcı Faktör Analizine Dayal1) [Scale development in behavioral sciences (Based on exploratory factor analysis)]. Turkish Journal of Family Medicine and Primary Care, 11(2), 108-126. https://doiorg/1021763/tjfmpc317880

Yıldırım, C. (2018). Ortaöğretim ögrencilerinin demokratik vatandaşlık tutumlarının resmi ve örtük program açisindan incelenmesi [The examination of the secondary education students' democratic citizenship attitudes towards the formal and hidden curriculum] [Doctoral thesis]. Adnan Menderes University.

Yıldırım, A., \& Şimşek, H. (2011). Sosyal bilimlerde nitel araştırma yöntemleri [Qualitative research methods in the social sciences]. Seçkin. 


\section{APPENDIX}

\section{Appendix-1: List of studies included in the research}

1. Acun, İ, Demir, M., \& Göz, N.L. (2010). Öğretmen adaylarının vatandaşlık yeterlilikleri ile eleştirel düşünme becerileri arasındaki ilişki [The relationship between student teachers' citizenship skills and critical thinking skills]. Journal of Social Studies Education Research, 1(1), 107-123. Retrieved from https://jsserorg/indexphp/jsser/article/view/119

2. Akın, A., Sarıçam, H., Akın, Ü., Yıldız, B., Demir, T., \& Kaya, M. (2014, April 28-30). The validity and reliability of the Turkish version of the global citizenship scale [Conference Presentation Abstract]. III International Social Studies Education Symposium (Isses III 2014), Ankara, Turkey.

3. Altıntaş, İ.N. (2016). Sosyal bilgiler öğretmen adaylarının aktif vatandaşlık kazanımları: eylem araştırmast [Active citizenship goals of social studies teacher candidates: Action research] [Doctoral thesis]. Gazi University.

4. Altık, A. (2019). Sosyal bilgilerde hizmet ederek öğrenmenin ögrencilerin iyi vatandaşlık algi, bilgi ve tutumlarına etkisi ve ögretmen görüşleri [The effect of the service-learning in social studies to the students' perception of good citizenship, their knowledge and attitudes and teachers' views] [Doctoral thesis]. Gazi University.

5. Arslan, H., Dil, K., Çetin, E., \& Yazıcı, S. (2017). Aktif yurttaşlık öz-yeterlik ölçeği: Bir geçerlik ve güvenirlik çalışması [Active citizenship self-efficacy scale: A reliability and validity study]. Journal of Human Sciences, 14(3), 2797-2809. http://dxdoiorg/1014687/jh sv14i34771

6. Arslan, S. (2014). Çokkültürlü toplumlarda vatandaşlık eğitimine yönelik öğretmen ve ögrenci dü̈süncelerinin incelenmesi [Examination of teacher and student opinions on citizenship education in multicultural societies] [Doctoral thesis]. Marmara University.

7. Balbağ, N.L. (2016). İlkokul sosyal bilgiler dersi bă̆lamında ögrenci ve ögretmenlerin küresel vatandaşlık algllarl [Elementary teachers' and students' perceptions of global citizenship in the social studies course] [Doctoral thesis]. Anadolu University.

8. Baştürk, N. (2011). Illköğretim 8 sinıf vatandaşlık ve demokrasi ĕgitimi dersi öğretim programı kazanımlarının öğrenci görüşlerine göre değerlendirilmesi (Konya ili örnĕ̆i) [Evaluation of the elementary 8th grade citizenship and democracy education course learning outcomes according to student views (Case of Konya)] [Doctoral thesis]. Atatürk University.

9. Bozbek, M., \& Demir, S.B. (2014). Vatandaşlık ve demokrasi eğitimi dersine yönelik tutum ölçeği; Geçerlik ve güvenirlik çalışması [Attitude scale towards citizenship and democracy education lesson: Development, validity and reliability study]. Dicle University Journal of Ziya Gökalp Education Faculty, 23, 323-351.

10. Çevik Kansu, C. (2014). Illkokul 4 sınıf ögrencilerinde etkin vatandaşlık eğitiminin etkililiği [Efficiency of Active Citizenship Education on 4th Grade of Primary Students] [Doctoral thesis]. Ondokuz Mayıs University.

11. Çiçek, S. (2018). Sosyal bilgiler öğretmen adaylarının iyi vatandaşlık algılarının incelenmesi [Examining the perceptions of the social studies teacher candidates towards good citizenship] [Master's thesis]. Akdeniz University.

12. Demirbaş, İ. (2016). Üniversite öğrencilerinin vatandaşlı algısının belirlenmesi [The determination of the university students' citizenship perception] [Master's thesis]. Kastamonu University.

13. Doğanay, A. (2009, May 28-30). Evaluation of pre-service teachers' perception of citizenship and their actions in the context of political socialization [Conference Presentation Abstract]. 1st International European Union, Democracy, Citizenship and Citizenship Education Symposium, Uşak, Turkey. 
14. Durualp, E. (2016). Ortaokul öğrencilerinin vatandaşlık algılarının bazı sosyolojik değişkenler açısından incelenmesi [Investigation of citizenship perception of middle school students from the point of some sociological variables] [Doctoral thesis]. Ankara University.

15. Elçi, A.C., \& Sarı, M. (2016). Bilişim Teknolojileri ve Yazılım dersinde dijital vatandaşlık Bir ölçek geliştirme çalışması [Digital citizenship in the Information Technology and Software course: A scale development study]. Journal of Human Sciences, 13(2), 36023613. http://dxdoiorg/1014687/jhsv13i23838

16. Erdem, C., \& Koçyiğit, M. (2019, April 25-28). Adapting the digital citizenship scale to Turkish: validity and reliability study [Conference presentation abstract]. 28th International Conference on Educational Sciences (ICES 2019), Ankara, Turkey.

17. Göl, E. (2013). Sosyal bilgiler ögretmen adaylarının küresel vatandaşlık tutum düzeylerinin farkl değişkenler açısından incelenmesi [The examination of global citizenship attitude levels of social studies nominee instructors according to different variants] [Master's thesis]. Ahi Evran University.

18. Gürbüz, G. (2006). Illköğretim 7 ve 8 sinıflarda vatandaşlık bilgisi dersinde demokrasi eğitimi [Democracy education of elementary school at 7th and 8th classes at citizenship lesson] [Doctoral thesis]. Abant İzzet Baysal University.

19. İçen, M., Öztürk, C., \& Yılmaz, A. (2017). Vatandaşlık duygusu ölçeği güvenirlik ve geçerlik çalışması [Validity and reliability of the sense of citizenship scale]. International Journal of Field Education, 3(2), 26-36. https://doiorg/1032570/ijofe370382

20. İkinci, İ. (2016). Sosyal bilgiler ögretmenlerinin vatandaşlık algllarl ve vatandaşlı eğitimi ile ilgili düşüncelerinin incelenmesi [Investigation of social studies teachers' perceptions of citizenship and citizenship education] [Doctoral thesis]. Dumlupinar University.

21. İşman, A., \& Güngören, Ö.C. (2014). Dijital Vatandaşlık [Digital citizenship]. TOJET: The Turkish Online Journal of Educational Technology, 13(1), 73-77.

22. Karaduman, H. (2011). 6 sinıf sosyal bilgiler dersinde dijital vatandaşlı̆̆a dayalı etkinliklerin öğrencilerin dijital ortamdaki tutumlarına etkisi ve ögrenme öğretme sürecine yansimalart [The effects of digital citizenship based activities on students' attitudes in digital environments and reflections to learning teaching process in the 6th grade social studies course] [Doctoral thesis]. Marmara University.

23. Karatekin, K., \& Uysal, C. (2018). Ekolojik vatandaşlık ölçeği geliştirme çalışması [Ecological citizenship scale development study]. International Electronic Journal of Environmental Education, 8(2), 82-104.

24. Karışan, D., \& Yılmaz Tüzün, Ö. (2017). Dünya vatandaşlığı için karakter ve değerler ölçeğinin Türkçe'ye uyarlanması: Geçerlik ve güvenirlik çalışması [Adaptation of character and values as global citizen assessment questionnaire into Turkish: Validity and reliability study]. Pamukkale University Journal of Education, 42, 74-85. http://dxdoiorg/ 109779/PUJE823

25. Kaya, B. (2013). Sosyal bilgiler öğretmen adaylarının vatandaşlık algıları ile politik ilgi ve katılımları arasındaki ilişkinin incelenmesi [Examining the relationship between citizenship perceptions of social studies teacher candidates and their political interests and participation] [Doctoral thesis]. Marmara University.

26. Kaya, B., \& Ersoy, A. F. (2014). Vatandaşlık ve demokrasi eğitimi dersinin sekizinci sınıf öğrencilerinde vatandaşlık algısının oluşmasıyla ilişkisi [The effect of citizenship and democracy on eight class students growing as a conscious citizen]. Dicle Üniversitesi Ziya Gökalp Ĕ̈itim Fakültesi Dergisi, 23, 252-303.

27. Kılınç, E., \& Dere, İ. (2013). Lise öğrencilerinin 'iyi vatandaş' kavramı hakkındaki görüşleri [High school students' perception of the concept of 'good citizen]. Journal of Social Studies Education Research, 4(2), 103-124. 
28. Kılınç, H.H. (2013). 8 sınıf vatandaşlık ve demokrasi eğitimi dersi kazanımlarının gerçekleşme düzeyine ilişkin ögretmen-öğrenci görüşleri ile derse yönelik öğrenci tutumlar [Teachers' and students' perceptions of realization level of 8th grade citizenship and democracy education course learning attainments and students' attitudes towards the course] [Doctoral thesis]. Firat University.

29. Kocadağ, T. (2012). Öğretmen adaylarının dijital vatandaşlık düzeylerinin belirlenmesi [Determining the digital citizenship levels of prospective teachers] [Master's thesis]. Karadeniz Teknik University.

30. Kuş, Z., Güneş, E., Başarmak, U. \& Yakar, H. (2017). Gençlere yönelik dijital vatandaşlık ölçeğinin geliştirilmesi: Geçerlik ve güvenirlik çalışması [Development of a digital citizenship scale for youth: A validity and reliability study]. Journal of Computer and Education Research, 5(10), 298-316. https://doiorg/1018009/jcer335806

31. Malkoç, S. (2020). Sosyal bilgiler ögretmenlerinin vatandaşlı tiplerinin belirlenmesi [Determination of the citizenship types of social studies teachers] [Doctoral thesis]. Gazi University.

32. Öntaş, T., Çoban, O., \& Atmaca, T. (2020). Adaptation of civic education ideologies scale to the Turk culture: It's reliability and validity [Vatandaşlık eğitimi ideolojileri ölçeğinin Türk kültürüne uyarlanması: Güvenirlik ve geçerlik çalışması]. International Journal of Social Science Research, 9(1), 1-20.

33. Özdemir Özden, D. (2011). İlköğretim okullarında çevresel vatandaşlık eğitimi [Environmental citizenship education in primary schools] [Doctoral thesis]. Marmara University.

34. Sabanc1, O. (2008). Illköğretim 7 sinıf ögrencilerinin sosyal bilgiler dersinde yer alan vatandaşlık konularlyla ilgili kavramsal anlamaları [Elementary school 7th grade students' conceptual understandings related to the citizenship subjects taking place in social studies course] [Doctoral thesis]. Gazi University.

35. Sağlam, H. (2011). Öğretmen adaylarının etkili vatandaşlik yeterlik düzeyleri [Proficiency levels of student teachers effective citizenship]. Kastamonu Education Journal, 19(1), 3950.

36. Som Vural, S. (2016). Üniversite öğrencilerinin bakış açısıyla dijital vatandaşlık göstergelerinin incelenmesi [Investigation of digital citizenship indicators through university students' perceptions] [Doctoral thesis]. Anadolu University.

37. Şahin, İ.F., \& Çermik, F. (2014). Küresel vatandaşlık ölçeğinin Türkçeye uyarlanması: Güvenirlik ve geçerlik çalışması [Turkish adaptation of global citizenship scale: Reliability and validity]. Eastern Geographical Review, 31, 207-218.

38. Şahin, M., Şahin, S., \& Göğebakan Yıldız, D. (2016). Sosyal bilgiler eğitimi programı ve dünya vatandaşlığı: Öğretmen adaylarının perspektifinden [The curriculum of social studies education and World citizenship: From perspective of prospective teachers]. Hacettepe University Journal of Education, 31(2), 369-390. http://dxdoiorg/1016986/HUJE2016015 $\underline{386}$

39. Tarhan, E. (2019). Vatandaşlı bağlamında sosyal bilgiler öğretmen adaylarının vatanseverlik tutumlarl ve görüşleri [Patriotism attitudes and views of preservice social studies teachers within the context of citizenship] [Master's thesis]. Bolu Abant İzzet Baysal University.

40. Tonga, D. (2013). 8 sınıf öğrencilerinin vatandaşlık bilinci düzeylerinin çeşitli değişkenler açısından değerlendirilmesi [Evaluation of the levels of citizenship consciousness of students grade 8 in terms of several variables] [Doctoral thesis]. Gazi University.

41. Türküresin, K. (2019). Ortaokul ögretmenlerinin dijital vatandaşlık davranışlarının incelenmesi [Investigation of digital citizenship behaviors of middle school teachers] [Master's thesis]. Dumlupınar University. 
42. Utku, M. (2015). Üniversite ögrencilerinin vatandaşlık ve sosyal medya (sosyal ăg) vatandaşlık algisının çeşitli değişkenlere göre incelenmesi [Examining perceptions of citizenship and perceptions of citizenship to social media on students of university according to various variables] [Doctoral thesis]. Erzincan University.

43. Ünal, F. (2019). Developing the citizenship skills scale: a validity and reliability study [Conference Presentation Abstract]. Ejer Congress Conference Proceedings, pp 442-446, An1.

44. Ünal, F. (2019). Ortaokul 8 sinıföğrencilerinin hak, sorumluluk ve katılımcılık bă̆lamında vatandaşlık bilincine ilişkin görüşlerinin hammond modeliyle değerlendirilmesi [The evaluation of the views of secondary school 8th year student on citizenship consciousness in the context of right, responsibility and participation using hammond's model] [Doctoral thesis]. Bartın University.

45. Ünal, F. (2019, April 25-28). Developing citizenship knowledge scale: Validity and reliability study [Conference Presentation Abstract] XII International Educational Research Congress, Rize, Turkey.

46. Yazgan, A.D. (2013). Öğretmen adaylarının medya okuryazarlık düzeyleri ile aktif vatandaşlı̆̆a ilişkin demokratik değer düzeyleri arasındaki ilişki [The relationship between preservice teachers' levels of media literacy and their democratic value for active citizenship] [Doctoral thesis]. Çanakkale Onsekiz Mart University.

47. Yazıcı, S., Arslan, H., Çetin, E., \& Dil, K. (2017). Aktif yurttaşlık ölçme aracının geliştirilmesi üzerine bir çalışma [A study on the development of active citizen questionnaire]. International Periodical for the Languages, Literature and History of Turkish or Turkic, 12(13), 1-22. http://dxdoiorg/107827/TurkishStudies 11645

48. Yıldırım, C. (2018). Ortaöğretim öğrencilerinin demokratik vatandaşlık tutumlarının resmi ve örtük program açısından incelenmesi [The examınation of the secondary education students' democratıc citızenship attitudes towards the formal and hidden curriculum] [Doctoral thesis]. Adnan Menderes University.

49. Yıldırım, Y., \& Çalışkan, H. (2020). Ortaokul öğrencileri için etkin vatandaşlık değerleri ölçeğinin (evdö) geliştirilmesi [Developing effective citizenship values scale (ecvs) for secondary school students]. Millî Ĕ̈itim, 49(228), 335-364. Retrieved from https://doiorg/1037669/milliegitim742091

50. Yiğen, V. (2019). Etkili vatandaş yetiştirmede sosyal bilgiler dersinin rolü [The role of social studies in raising effective citizenship] [Master's thesis]. İnönü University. 


\section{Appendix-2: The checklist used in the study}

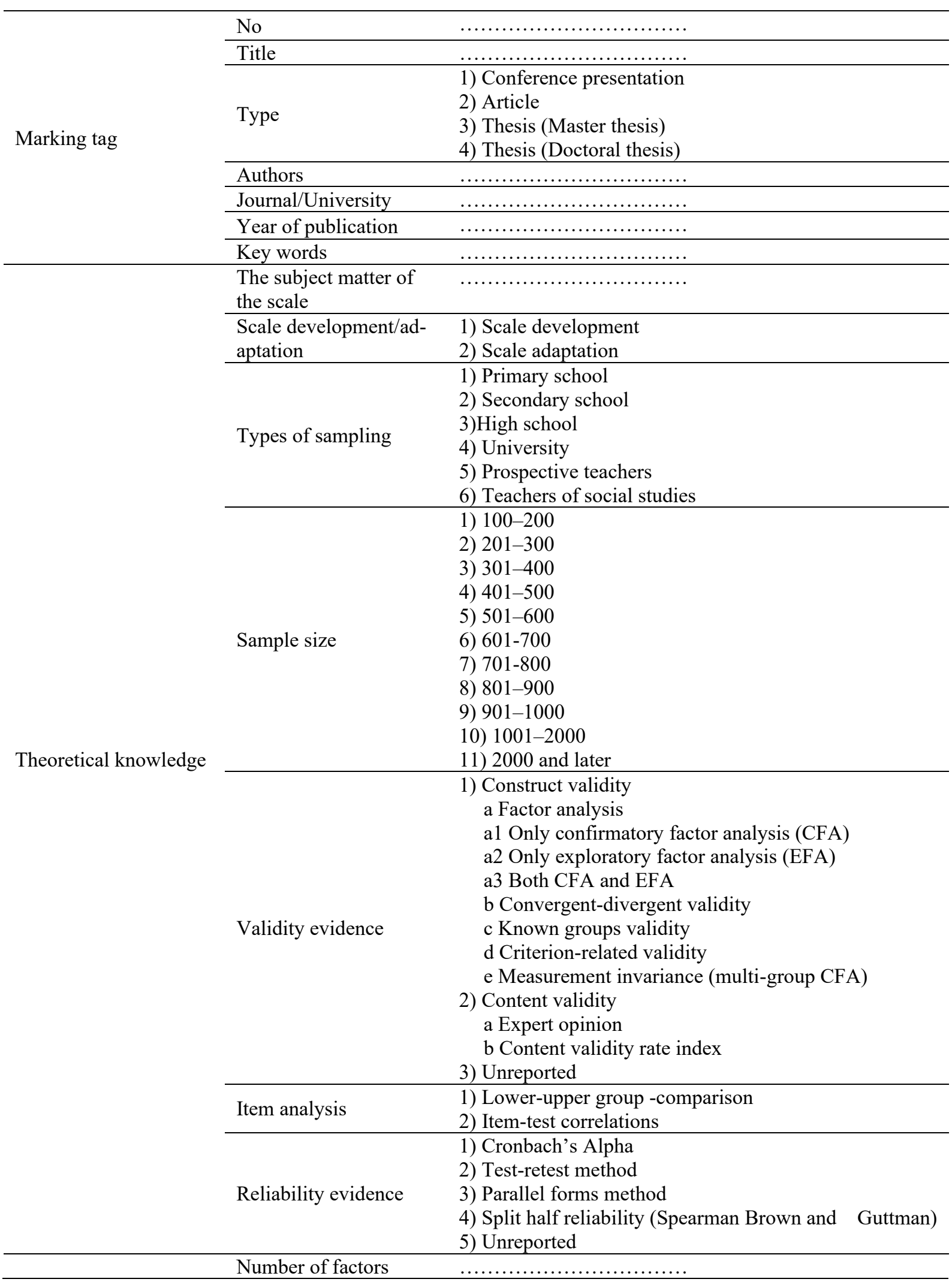

